\title{
Development of pharmaceutical care tools for people living with HIV treated at a
}

\section{medium- and high-complexity hospital}

\author{
Desenvolvimento de instrumentos para o cuidado farmacêutico de pessoas vivendo com HIV \\ atendidas em um hospital de média e alta complexidade \\ Desarrollo de herramientas del seguimiento farmacoterapéutico para personas viviendo con VIH
} atendidas en un hospital de mediana y alta complejidad

\begin{abstract}
The exposure of people living with HIV (PLHIV) to antiretrovirals (ARV) can cause significant adverse effects, contributing to their low adherence to treatment. The pharmacist can contribute to the optimization of PLHIV drug therapy through pharmacotherapeutic monitoring, favoring adherence to ARV therapy and, consequently, suppression of the viral load. The objective of the present study was to develop a pharmacotherapeutic monitoring routine for PLHIV in outpatient follow-up at a medium- and high-complexity hospital in the city of Rio de Janeiro. This is an experimental development project that consists of using knowledge from practical experience and research from the specialized literature to subsidize the structuring of a new service to support PLHIV. The work was divided into three parts: development of the necessary instruments for pharmaceutical care, elaboration of standard operating procedures (SOPs) for patient care, and testing of routines and work tools. The educational leaflets for patients and information boards were developed through a literature search, whereas the pharmaceutical documentation instruments and SOP were developed through adaptations of the Dáder Method. All work instruments were subjected to a test to evaluate the need for changes to improve the service.
\end{abstract}

Keywords: HIV; Anti-retroviral agents; Pharmaceutical services.

\begin{abstract}
Resumo
A exposição de pessoas vivendo com HIV (PVHIV) aos antirretrovirais (ARV) pode causar efeitos adversos significativos, contribuindo para sua baixa adesão ao tratamento. $\mathrm{O}$ farmacêutico pode contribuir para a otimização da terapia medicamentosa da PVHIV por meio do acompanhamento farmacoterapêutico, favorecendo a adesão à terapia ARV e, consequentemente, a supressão da carga viral. $\mathrm{O}$ objetivo do presente estudo foi desenvolver uma rotina de acompanhamento farmacoterapêutico para PVHIV em acompanhamento ambulatorial em um hospital de média e alta complexidade da cidade do Rio de Janeiro. Trata-se de um projeto de desenvolvimento experimental que consiste na utilização de conhecimentos oriundos da experiência prática e de pesquisas da literatura especializada para subsidiar a estruturação de um novo serviço de atendimento às PVHIV. O trabalho foi dividido em três partes: desenvolvimento dos instrumentos necessários para o cuidado farmacêutico, elaboração de procedimentos operacionais padrão (POPs) para o atendimento ao paciente e testes de rotinas e ferramentas de trabalho. Os folhetos educativos para pacientes e os painéis informativos foram desenvolvidos por meio de pesquisa bibliográfica, enquanto os instrumentos de documentação farmacêutica e POP foram desenvolvidos por meio de adaptações do Método Dáder. Todos os instrumentos de trabalho foram submetidos a um teste para avaliar a necessidade de alterações para melhoria do serviço.
\end{abstract}

Palavras-chave: HIV; Antirretrovirais; Serviços Farmacêuticos. 


\begin{abstract}
Resumen
La exposición de las personas que viven con el VIH (PVVIH) a los antirretrovirales (ARV) puede provocar efectos adversos importantes, lo que contribuye a su baja adherencia al tratamiento. El farmacéutico puede contribuir a la optimización de la farmacoterapia de las PVVIH mediante el seguimiento farmacoterapéutico, favoreciendo la adherencia a la terapia ARV y, en consecuencia, la supresión de la carga viral. El objetivo del presente estudio fue desarrollar una rutina de monitorización farmacoterapéutica para PVVIH en seguimiento ambulatorio en un hospital de mediana y alta complejidad de la ciudad de Río de Janeiro. Se trata de un proyecto de desarrollo experimental que consiste en utilizar el conocimiento de la experiencia práctica y la investigación de la literatura especializada para subsidiar la estructuración de un nuevo servicio de apoyo a las PVVIH. El trabajo se dividió en tres partes: desarrollo de los instrumentos necesarios para el seguimiento farmacoterapéutico, elaboración de procedimientos operativos estándar (POE) para la atención al paciente y prueba de rutinas y herramientas de trabajo. Los folletos educativos para pacientes y los tableros informativos se desarrollaron mediante una búsqueda bibliográfica, mientras que los instrumentos de documentación farmacéutica y los POE se desarrollaron mediante adaptaciones del Método Dáder. Todos los instrumentos de trabajo fueron sometidos a una prueba para evaluar la necesidad de cambios para mejorar el servicio.
\end{abstract}

Palabras clave: VIH; Antirretrovirales; Servicios farmacéuticos.

\title{
1. Introduction
}

Infection caused by human immunodeficiency virus (HIV) has three distinct clinical phases: acute infection, the clinical latency or asymptomatic phase, and acquired immune deficiency syndrome (AIDS). Acute HIV infection occurs in the first weeks of infection and is marked by intense viral replication in the lymph nodes. It is believed that a person living with HIV (PLHIV) who does not use any regimen involving medications will gradually evolve over an average time of 10 years between the first contact with the virus and the onset of AIDS (Brasil, 2018; São Paulo, 2017).

According to the epidemiological survey of the World Health Organization (WHO), there were approximately 37.7 million people living with HIV/AIDS worldwide at the end of 2020. Within this population, 27.5 million people were accessing antiretroviral therapy, up from 7.8 million in 2010 (WHO, 2021).

In 2014 the Joint United Nations Programme on HIV and AIDS (UNAIDS) set a target known as the 90-90-90, that predicted that, by the end of 2020,90\% of all PLHIV will know their HIV status, $90 \%$ of all diagnosed will receive adequate antiretroviral (ARV) therapy and $90 \%$ of those undergoing treatment will reach the undetectable level of viral load. This goal highlights the importance of adherence to antiretroviral therapy (UNAIDS, 2020; Souza, et al., 2019).

The emergence of ARV drugs to treat HIV began in the 1980s, with the discovery of zidovudine (AZT), a nucleoside reverse transcriptase inhibitor (NRTI). The treatment of the infection has been continuously modified ever since, and new drugs have been introduced into therapeutic practice (Bruton et al., 2018).

The exposure of patients to ARVs can cause toxicity and significant adverse reactions, which contributes to low adherence or abandonment of treatment. The lack of adherence by patients can result in serious damage to the immune system, reflected in low levels of T-cell CD4+ lymphocytes and, consequently, increasing the speed of their progression to the development of AIDS (Moraes et al., 2014).

The quality of medication dispensing, considering that the patient must receive all the appropriate information about the treatment, and the relationship established between patients and healthcare professionals have a positive impact on treatment success and adherence to drug therapy (Silva, et al, 2015; Souza, et al., 2019; Toledo, et al, 2019).

Accordingly, pharmaceutical care (PC) of PLHIV has an important role in the management of therapy, guidance on the use of medications, controlling and reducing adverse effects and reducing the frequency of the need to take pills, contributing to better adherence to treatment and, consequently, to the suppression of viral load (Brasil, 2010; Martinez, 2012; Rocha, et al, 2015; Toledo, et al, 2019). 


\section{Methodology}

This is an experimental development project that consists of using knowledge from practical experience and research of the specialized literature to subsidize the structuring of a new service (Gil, 2018).

The PC tools were developed using what is recommended by the Dáder Method of pharmacotherapeutic follow-up. The questions of the self-report method established by Morisky-Green were used to assess adherence to ARVs (Hernández et al., 2007; Morisky, 1986).

To assist the workflow in the PC service and understand the application of the tools developed, three standard operating procedures (SOPs) were developed to guide the execution of the activities. The SOPs were prepared in compliance with the rules and the model recommended by the institution of the research scenario, and the development of each SOP was guided by the pharmacotherapeutic follow-up model described in the Dáder method.

Other complementary tools to support the PC were also developed, such as informational tables of adverse effects, mechanism of action and main observations of ARVs and educational leaflets for patients.

Once elaborated, the tools were evaluated and approved by the team of pharmacists and doctors. Right after, the routine and the instruments were subjected to a test to verify the need for some modifications to better serve the patients and meet their health demands. The test was developed over two months and comprised a two-hour training course, consisting of a face-to-face presentation with all of the pharmaceutical professionals who were part of the service team, and evaluation of the applicability of all tools in clinical practice.

The training approached all the steps of the PC routine, from the offer of the service, evidencing the inclusion criteria for patient participation, to the detailing of the first consultation, assessment of the patient's status, identification of problems related to medication, preparation of the action plan and the service flow for successive consultations.

\section{Results and Discussion}

\subsection{Development of follow-up forms and pharmacotherapeutic follow-up routines}

One of the first steps during the process of implementing a PC service focuses on the development of instruments for the correct documentation of information. Through data collection tools, the pharmacist is able to understand clinical and pharmacoepidemiological data and other information to provide care. Thus, information management is essential for the quality of healthcare, and the pharmacist must adopt specific methods for clinical records that favor the standardization of conduct (Reis, 2014; Shouter \& Novaes, 2007).

The choice of the method to be used depends directly on the training and practice of the professional who will start the service, in addition to the profile of the population served and the characteristics of the care setting itself. The service was structured by a pharmacist who was attending a hospital pharmacy residency program, where he acquired clinical training in the practice of CP. For this reason, it was decided to adopt the pharmacotherapeutic follow-up model recommended by Hernández, Castro and Dáder (2007), as it presents a more extensive and complete approach.

These characteristics of the method allow the most inexperienced pharmacists to easily understand the pharmaceutical care process and to better conduct the consultation. As the pharmacist becomes more experienced and familiar with the patient follow-up, one can opt for simpler and subjective methods (Hurley, 2004).

The Dáder method divides the pharmacotherapeutic follow-up into seven different stages (service offer, pharmaceutical interview, state of the situation, study phase, evolution phase, intervention phase and successive interviews), and the forms were developed according to the needs of each PC phase. Each stage includes a series of questions that will 
support the construction of the patient's clinical history. Modifications to the Dáder method must be carried out to adapt it to the peculiarities of the population served and the feasibility of its application to the service (Hernández, Castro \& Dáder, 2007).

Considering that the service is not able to offer pharmacotherapeutic follow-up to all patients, it was necessary to define eligibility criteria to prioritize care for those who may benefit the most. As eligibility criteria for PLHIV, the service offer must occur when identifying patients for the initiation of or making changes to their ART, those with a high viral load and those who had interruptions and/or delays in the dispensing of medications. During the time of service offer, it is important that the pharmacist explain, in a clear and concise manner, the provision of care that the patient will receive (Brasil, 2018; Hernández et al., 2007).

Pharmaceutical interviews with the patient are the basis of the pharmacotherapeutic follow-up, and the progress/result of this practice depends on the success in establishing good communication between the pharmacist and the patient. The first pharmaceutical interview aims to collect information about the patient's health problems and their pharmacotherapeutic history and to document all of the information, and thus an initial contact pharmaceutical interview form must be developed (Hernández et al., 2007).

The first interview form was developed to obtain initial information about the health problems and medications used by the patient, in order to start their pharmacotherapeutic history. The form was structured to include four parts: initial patient data (clinical and sociodemographic), health problems, medications used and review by the systems. Each of the topics included in the first pharmaceutical interview form was developed in compliance with the recommendations of the Dáder method to establish a solid and comprehensive database. In the first contact with the patient, the pharmacist should be concerned with making a welcoming reception, avoiding any kind of judgment, prejudice and other negative attitudes (Hernández et al., 2007; Toledo, et al, 2019).

After the first pharmaceutical consultation, the pharmacotherapeutic follow-up proceeded to the phase of analysis of the state of the situation. The form used during this phase was developed in order to briefly show the relationship between the main health problems and the medications used by the patient, on a given date. The document was prepared considering that the analysis of the state of the situation should be continuously observed at each consultation carried out.

As one of the goals of this phase is to observe the global panorama of the patient's health, important clinical aspects to evaluate in PLHIV were added to the Situational Analysis Form, such as: antiretroviral drugs in use, last T-cell CD4+ count, last viral load test result. It is important to assess CV parameters and T-cell CD4+ levels, since they are considered the main clinical indicators of PLHIV to assess the success of drug therapy and the prognosis of the infection (Felix \& Ceolim, 2012; Reis, 2014; Santos et al., 2010; Silveira et al, 2014).

The data collected during the study phase regarding the patient's health and medication problems will serve as support for the intervention phase and preparation of the Action Plan Form (Hernández et al., 2007).

The form for the intervention phase (action plan) was designed in order to detail and rank the defined objectives, in addition to determining and planning the pharmaceutical interventions adopted to improve the patient's health status. The action plan must be a continuous work performed over time and carried out with the involvement of the patient, and its form must be able to register all of the pharmaceutical interventions that will be carried out to improve the patient's health status. Each pharmaceutical intervention performed must also be recorded on the Pharmaceutical Intervention Form.

As pointed out in some pharmacotherapeutic follow-up studies carried out with PLHIV, pharmaceutical interventions have a positive impact on clinical prognosis by improving adherence and, consequently, suppressing the viral load and increasing the T-cell CD4+ count. In general, measuring the real impact of pharmaceutical interventions is only possible 
through the pharmacist's monthly and systematic performance through pharmacotherapeutic follow-up (Ma et al, 2010; Reis, 2014).

The end of the pharmacotherapeutic follow-up process occurs after the action plan phase and the consequent resolution of pharmaceutical interventions. The form used in subsequent interviews was designed in order to identify the patient's and/or physician's response to the pharmaceutical intervention proposal, prove the continuity of the intervention, obtain information about the result of the pharmaceutical, to identify new health problems and to add new drugs. Successive interviews must be registered by completing the Return Pharmaceutical Interview Form.

\subsection{Development of educational leaflets and informational tables}

The structured model of the pharmacotherapeutic follow-up aims to provide patients with accurate information about the drugs used in the ARV scheme, to help develop coresponsibility with their treatment and to promote adherence to antiretroviral therapy.

The pharmacist must transmit to the patient all of the knowledge necessary to achieve the correct use of the medications and, consequently, obtain the maximum benefit from antiretroviral therapy. The information provided must be easy to understand, using simple language, and it is essential to have support tools that facilitate communication, such as printed leaflets with appropriate illustrative images (Codina, et al, 1999).

As a main strategy, two educational leaflets were developed addressing questions about HIV/AIDS and about antiretroviral schemes. The information covered in both educational leaflets must be presented verbally to the patient during the PC in the office.

Still in the context of health education, seeking to promote greater safety in antiretroviral pharmacotherapy and aiming to assist pharmaceutical professionals quickly and effectively, a table was structured containing general information about standardized ARVs in the study scenario. These tools address the main drug interactions observed between ARV and other drugs, adverse effects, therapeutic class, information about medication administration, etc.

In this way, the pharmacist was able to optimize the information process and transmit knowledge directed to the specific needs of each patient regarding the rational use of medicines.

\subsection{Development of standard operating procedures for the pharmacotherapeutic follow-up routine}

The flow of the pharmacotherapeutic follow-up service with PLHIV was based on the one recommended by the Dáder method (Hernández et al., 2007).

To better understand the processes involved in each step of the flow, it was decided to develop three SOPs: service offer, scheduling and communication with the patient; initial pharmaceutical consultation; and clinical analysis after the first consultation and return consultation.

The performance of the activities detailed in the SOPs must be in line with current laws and resolutions that provide guidelines and recommendations for the exercise of the pharmaceutical profession, focusing on their clinical duties.

\subsection{Evaluating routine and pharmaceutical care tools}

As the objective of the work was to implement a new routine in the service, the validation of the tools was not carried out, which was the main limitation of the work. The forms of pharmacotherapeutic follow-up were applied in the routine of care for a period of two months by the service team itself to verify if it was feasible, that is, if it was able to conduct the entire 
consultation and register the relevant information and in a time compatible with the other service routines, and if there was a need for adjustments (formatting, form configuration, fields that can be excluded/ included/repositioned).

The forms proved to be efficient in collecting specific data from patients, enabling greater knowledge about the socioeconomic profile, lifestyle and health condition. The other instruments developed (educational leaflets and information boards) were also applied in practice and supported the health education process, facilitating the pharmaceutical interventions.

During the testing of the routine and the instruments, it was also possible to identify some difficulties that guided changes in the structure of the service and the instruments themselves.

Regarding the initial stage (service offer, scheduling and communication with the patient), the patient scheduling spreadsheet was updated, and during the appointment, the pharmacist started to request an updated contact phone and establish an exact time to perform the service.

The completion of the patient identification items and clinical characteristics was begun before starting the consultation to reduce the patient's service time. The other instruments did not undergo any changes after the test phase.

The importance of the test was to verify the main limitations of the care routine and the instruments to arrive at the most appropriate results for monitoring patients in this study setting. Even so, PC, even after effective implantation, remained subject to changes according to the pharmacist's perception.

\section{Conclusion}

The SOPs and the tools developed served to guide the work, standardize the conduct, guarantee the reproduction of the pharmaceutical care routine through pharmacotherapeutic follow-up in a safe way and guarantee the systematic registration of the related information, including enabling the future development of more robust studies.

The test to evaluate the tools developed and the SOPs served to identify some needs for adjustments and allowed for focusing on measures to promote the necessary improvements. All tools proved to be adequate during the practice of pharmaceutical care.

As it is a well-defined work, the development of the tools and routine of care has contributed effectively to the feasibility of the proposed service and has shown its relevance in promoting the correct care and reception of people living with HIV in the study scenario.

The support of the institution and the entire team involved were essential for the development of the project, mainly due to the recognition of the importance of pharmaceutical care in the lives of PLHIV and for guidance during the elaboration of the tools and structuring of the service.

The PC in the study setting must continue under constant evaluation and changes, as it is a service that is being carried out for the first time along the lines elaborated by this work. As this is a first step towards the effective implementation of the $\mathrm{PC}$, the team that continues to provide assistance must remain in constant attention and elaborate strategies that prioritize the reception of patients who most need follow-up.

\section{Acknowledgments}

We are grateful to NAM - a charity organization based in the United Kingdom that works with people with HIV/AIDS - for the images provided for the preparation of the educational leaflets for patients. For more information, visit www.aidsmap.com. 
Research, Society and Development, v. 11, n. 1, e28511124965, 2022

(CC BY 4.0) | ISSN 2525-3409 | DOI: http://dx.doi.org/10.33448/rsd-v11i1.24965

\section{References}

Brasil. (2018). Protocolo Clínico e Diretrizes Terapêuticas para Manejo da Infecção pelo HIV em Adultos. http://www.aids.gov.br/pt-br/pub/2013/protocoloclinico-e-diretrizes-terapeuticas-para-manejo-da-infeccao-pelo-hiv-em-adultos

Brasil. (2010). Protocolo de Assistência Farmacêutica em DST/HIV/AIDS. https://bvsms.saude.gov.br/bvs/publicacoes/protocolo_ assistencia_farmaceutica_aids.pdf.

Bruton, L. L., Chabner, B. A., \& Knollmann, B. C. (2018). As Bases Farmacológicas da Terapêutica de Goodman e Gilman. AMGH.

Codina, C., Tuset, M., Martínez, M., \& del Cacho, E. (1999). Adherencia tarv/tbc. Programa de atención farmacéutica. Revista Española de Sanidad Penitenciaria, 1 (4), 132-134. http://www.sanipe.es/OJS/index.php/RESP/article/view/157/357

Felix, G., \& Ceolim, M. F. (2012). O perfil da mulher portadora de HIV/AIDS e sua adesão à terapêutica antirretroviral [The profile of women with HIV/AIDS and their adherence to the antiretroviral therapy]. Revista da Escola de Enfermagem da USP, 46 (4), 884-891. https://doi.org/10.1590/S008062342012000400015

Gil, A.C. (2018). Como elaborar projetos de pesquisa. Atlas.

Hernandéz, D. S., Castro, M. M. C., \& Dáder, M. J. F. (2007). Método Dáder: Guía de Seguimiento Farmacoterapéutico. https://www.unifalmg.edu.br/gpaf/wp-content/uploads/sites/74/2018/09/Guia-dader-interior-brasil-v4_.pdf.

Hurley, S. C. (1998). A method of documenting care utilizing pharmaceutical diagnosis. American Journal of Pharmaceutical Education, 62, 119-127. https://citeseerx.ist.psu.edu/viewdoc/download?doi=10.1.1.600.6009\&rep=rep1\&type=pdf

Ma, A., Chen, D. M., Chau, F. M., \& Saberi, P. (2010). Improving adherence and clinical outcomes through an HIV pharmacist's interventions. AIDS care, 22 (10), 1189-1194. https://doi.org/10.1080/09540121003668102

Martinez, A. M. V. (2012). Modelo de atenção farmacêutica no tratamento com antirretrovirais, em clínica de DST/AIDS no município de Sorocaba, SP, Brasil. [Master's thesis, Universidade de Sorocaba]. http://farmacia.uniso.br/producao-discente/dissertacoes/2012/ADRIANA_MARTINEZ.pdf.

Moraes, D. C. A., Oliveira, R. C., \& Costa, S. F. G. (2014). Adesão de homens vivendo com HIV/Aids ao tratamento antirretroviral. Revista de Enfermagem Escola Anna Nery, 18 (4), 676-681. https://doi.org/10.5935/1414-8145.20140096

Morisky, D. E., Green, L. W., \& Levine, D. M. (1986). Concurrent and predictive validity of a self-reported measure of medication adherence. Medical Care, 24 (1), 67-74. https://doi.org/10.1097/00005650-198601000-00007

Rocha, B. S., Silveira, M. P., Moraes, C. G., Kuchenbecker, R. S., \& Dal-Pizzol, T. S. (2015). Pharmaceutical interventions in antiretroviral therapy: systematic review and meta-analysis of randomized clinical trials. Journal of Clinical Pharmacy and Therapeutics, 40 (3), 251-258. https://doi.org/10.1111/jcpt.12253

Reis, H. P. C. (2014). Acompanhamento de pessoas com HIV sob terapia antirretroviral: adequação, aplicação e avaliação de indicadores clínicolaboratoriais, farmacoterapêuticos e humanísticos na atenção farmacêutica. [Doctoral dissertation, Universidade Federal do Ceará]. http://www.repositorio.ufc.br/handle/riufc/10879.

Santos, C. N. R., Silva, L. R., \& Soares, A. Q. (2010). Perfil epidemiológico dos pacientes em terapia antirretroviral em seguimento na Universidade Federal de Goiás. Revista Eletrônica de Farmácia, 7 (3), 53-61. https://doi.org/10.5216/ref.v7i3.12896

São Paulo. Coordenadoria de Controle de Doenças. (2017). Diretrizes para Implementação da Rede de Cuidados em IST/HIV/Aids: Manual de Gestão da Rede e dos Serviços de Saúde. http://www.saude.sp.gov.br/resources/ crt/publicacoes/publicacoesdownload/diretrizes_para_implementacao_da_rede_de_cuidados_em_ist_hiv_aids_-_vol_i_-_manual_de_gestao_2.pdf.

Shouter, D., \& Novaes, H. M. D. (2007). Do registro ao indicador: gestão da produção da informação assistencial nos hospitais. Ciências Saúde Coletiva, 12 (4), 935-944. https://doi.org/10.1590/S1413-81232007000400015

Silva, J. A. G., Dourado, I., Brito, A. M., \& Silva, C. A. L. (2015). Fatores associados à não adesão aos antirretrovirais em adultos com AIDS nos seis primeiros meses da terapia em Salvador, Bahia, Brasil. Cadernos de Saúde Pública, 31 (6), 1188-1198. https://doi.org/10.1590/0102-311X00106914

Silveira, M. P., Guttier, M. C., Page, K., \& Moreira, L. B. (2014). Randomized controlled trial to evaluate the impact of pharmaceutical care on therapeutic success in HIV-infected patients in Southern Brazil. AIDS and behavior, 18 Suppl 1, S75-S84. https://doi.org/10.1007/s10461-013-0596-8

Souza, H. C. de, Mota, M. R., Alves, A. R., Lima, F. D., Chaves, S. N., Dantas, R. A. E., Abdelmur, S. B. M., \& Mota, A. P. V. da S. (2019). Analysis of compliance to antiretroviral treatment among patients with HIV/AIDS. Revista Brasileira de Enfermagem, 72 (5). https://doi.org/10.1590/0034-7167-20180115

Toledo, M. I., Silva, A. W. M., Silva, D. L. M., Silva, E. V., Oliveira, F. A. R., Nóbrega, H. V., et al. (2019). Cuidado Farmacêutico aos pacientes com HIV/AIDS. In L.C, Lopes, \& P, Caleb (Eds.), Cuidado Farmacêutico para Pacientes com Câncer, Hepatite, HIV/AIDS, Dengue e Outras Doenças (1st ed., pp. 171-190). Atheneu.

UNAIDS. (2020). 90-90-90: bom progresso, mas o mundo está longe de atingir as metas de 2020. https://unaids.org.br/2020/09/90-90-90-bom-progresso-maso-mundo-esta-longe-de-atingir-as-metas-de-2020/

World Health Organization. (2021). HIV/AIDS. https://www.who.int/data/gho/data/themes/hiv-aids. 